\title{
Ergenlerde İnternet Bağımlılığı ile Şema Mekanizmaları Arasındaki İlişki
}

\section{The Relationship Between Internet Addiction and Schema Mechanisms among Adolescents}

\author{
Feyza Aksoy ${ }^{1}$ (D), Hüseyin Ünübol ${ }^{1}$ (D)
}

1. Üsküdar Üniversitesi Sosyal Bilimler Enstitüsü Klinik Psikoloji Anabilim Dalı, İstanbul

\begin{abstract}
Objective: The aim of this study was to investigate the relationship between internet addiction and schema mechanisms of adolescents in a private high school sample.

Method: The study sample was based on a relational screening model with the participation of 148 volunteer students in a private Anatolian High School located in Üsküdar district of Istanbul province in the 2015-2016 Academic year. Data was collected using the Internet dependency scale, Young schema scale, and sociodemographic data form.

Results: The sample consists of 148 students, 75 of whom are girls, 72 of whom are boys, and 1 person who has not stated their gender, representing 14-18 age group who continue their education in their classes. There was no difference between internet addiction and gender, while there are significant differences between age groups. According to the purpose of using the Internet, addiction is highest in recreational use. In addition, a positive directional relationship was found between internet dependence and schema mechanisms.

Conclusion: Among 18 maladjusted schemas found in adolescents in the study group, a positive moderate strong relationship was found between imperfection, inadequate self-control and submissiveness schemas and internet
\end{abstract} addiction.

Keywords: Adolescents, internet addiction, schema mechanisms,

Öz

Amaç: Bu çalışmada özel lisede eğitimlerini sürdüren 14-18 yaşındaki ergenlerin internet bağımlıı̆ı ile şema mekanizmaları arasındaki ilişkinin araştıııması amaçlanmışıtır.

Yöntem: Çalışma Özel bir Anadolu Lisesindeki 148 gönüllü öğrencinin katılımılla ilişkisel tarama modeli esas alınarak yapıımıştır. Verilerin toplanmasında İnternet Bağımlılık Ölçeği, Young Şema Ölçeği, ve Sosyo-Demografik Bilgi Formu ile elde edilen bilgiler kullanılmıştır.

Bulgular: Örneklem; eğitimlerini sürdürmekte olan 14-18 yaş grubu ergenleri temsil eden 75'i kız, 72'si erkek, 1 kişide cinsiyetini belirtmemiş toplam 148 öğrenciden oluşmaktadır. İnternet kullanım özellikleri ile internet bağımlılık ölçeğine göre belirlenen gruplar arasındaki ilişki değerlendirildiğinde, internet bağımlı̆̆ğ ile cinsiyet arasında bir farkllık görülmezken yaş grupları arasında anlamlı farklııklar vardır. İnternet kullanım amacına göre ise eğlence amaçlı kullanımda bağımlılık en yüksek düzeydedir. Ayrıca internet bağımılı̆̆ı ve şema mekanizmaları arasında pozitif yönlü bir iliş̧ki bulunmuştur.

Sonuç: Çalışma grubunda yer alan ergenlerin 18 uyumsuz şema ile internet bağımlılı̆ı arasında kusurluluk, yetersiz özdenetim ve boyun eğicilik şemaları açısından pozitif yönlü orta kuvvetli anlamlı bir ilişki bulunmuştur.

Anahtar kelimeler: Ergenler, internet bağımlılığı, şema mekanizmaları 


\section{Giriş}

İnternet bağımllığı; internetin sağlıksız, aşııı veya uygunsuz kullanımı, kişide fazla internet kullanma arzusunun olması, internetsiz geçirilen vakitlerin değersiz olarak algılanması, internet erişimi olmadığında aşırı sinirlilik durumu ve agresif olunması gibi durumlar sonucunda bireyin meslek, sosyal ve aile yaşamının bozulması şeklinde ifade edilebilir (1). İnternet bağımlıı̆ı ilk yıllardan beri literatürlerde farklı şekillerde tanımlanmıştır. IIIk tanım ise 1995 yılında Ivan Goldberg tarafından yapılmıştır. Goldberg DSM-IV'teki madde bağımlılığı kriterlerinden esinlenerek internet bağımlıı̆ı rahatsızlığını dile getirmiştir. DSM-5'te ise "internet bağımılı̆̆ı" kavramı yerine "internet oyun oynama bozukluğu” kavramı yer almaktadır. DSM-5'te 9 tanı ölçütünden bahsedilmektedir. Bunlar; zihinsel meşguliyet, geri çekilme, tolerans, süreklilik, yerine geçme, sorunlar, yanıltma, kaçınma ve çatışmadır. Tolerans ve geri çekilme ölçütleri en önemli boyutlardır ve bu dokuz ölçütün 5i'nin son bir yılda görülmesi internet bağımlılığı olduğunu göstermektedir (APA 2013). Internet bağımlıı̆ı literatürlerde patolojik internet kullanımı, aşırı internet kullanımı, kompulsif internet kullanımı, problemli internet kullanımı, yanlış internet kullanımı, spesifik veya genelleştirilmiş internet kullanımı, uyumsuz internet kullanımı gibi farkı terimler ile ele alınmıştır. İnternet bağımılı̆̆ının tanımı; kişide duygusal, bilişsel ve davranış anomalilerine sebep olan, sosyal ve akademik yaşantıda olumsuz sonuçlara yol açan çok boyutlu bir sendrom şeklinde yapılabilir (2). En geniş tanımıyla internet bağımlılı̆ı ise, internette gereğinden fazla zaman harcama problemi olarak tanımlanabilir (3).

İnternet kullanımının en yaygın olarak görüldüğü popülasyon olan gençlerin ergenlik döneminde yaşadıkları kimlik krizi, duygusal iletişime yönelmeleri, meslek seçimi gibi kritik kararları verme sürecinde olmaları gibi çeşitli sorunların ortaya çıktığı bu dönemde gençler için internet hayatlarında önemli bir yer kaplamaktadır. Bu durum gençlerin internette geçirdikleri zamanı arttırmakta ve internet bağımlıı̆̆ını tetiklemektedir. İnternetin ve bilgisayar oyunlarının çok fazla kullanılmasının, ödül şeklinde değerlendirilmesi ve bunun sonucunda oluşan olumsuz duyguları kaygı, sıkıntı ve düş kırıkığı) ortadan kaldıracak bir yöntem olarak görülmesi internet kullanımına yönelimi artırmaktadır (4). Türkiye'de internet bağımlılığı 2000'li yılların başından itibaren araştırmacıların dikkatini çekmeye başlamıştır ve bu konuda birçok çalışma yayınlanmıştır. Bu çalışmalarda internet bağımlıı̆ının duygusal zeka, kişilik özellikleri, sosyal destek, psikolojik değişiklikler, internet kullanım şekli, farklı yaş gruplarında internet bağımlı̆̆ğı, psiko-sosyal değişkenler, bağımlıık seviyeleri gibi farklı değişkenler ile ilişkisi değerlendirilmiştir (5-14).

Şema terapi; bilişsel davranışçı, bağlanma, geştalt, obje ilişkileri, yapıcı ve psikanalitik terapilerin zenginliklerinin harmanlandığı bir terapi modelidir. Bu modele göre erken dönem uyumsuz şemalar psikopatolojinin temel kaynağı olarak görülmektedir. Erken dönem uyumsuz şemalar bireyin bebeklik ve çocukluk dönemlerinde yaşadığı olumsuz yaşam deneyimleri sonucu oluşan, bireyin kendisi ve dış dünya hakkındaki yargılarını içeren, sürekliliği ve kalıcılığı olan işlevsiz temel inançlar olarak tanımlanmaktadır (15). Şema terapi bilişsel davranışçı terapi uygulamalarından, sadece var olan semptomlar üzerinde değil, doğrudan bu semptomların gelişimi ile ilgilenme noktasında farkılık gösterir. Danışmada terapist ile danışan arasındaki ilişki düzeltici duygusal tecrübe ve empatik yüzleştirmenin oluşmaşna zemin hazırlar. Danışman terapiye yönelik net hedefler koyarak, danışanlarına bilişsel, duygusal, ilişkisel ve davranışsal kalıplarının değiştirilmesinde ve temel duygusal gereksinimlerini fark ederek karşılanmaları noktasında çeşitli yollar öğrenmelerine yardımcı olur (16). Şema terapi, özellikle bugüne kadar tedavisi güç olan, yerleşmiş süreğen psikolojik bozuklukların görüldüğü hastalar için uygun bir psikoterapi yöntemidir. İleri derecede kişilik bozukluğu olan hastalarda ve duygu durum, anksiyete, cinsellik, yeme, somatoform ve madde kullanımı bozukluklarını içeren Eksen I bozukluğu olan hastaların tedavisinde de olumlu sonuçlar vermiştir (17).

Şema terapi alanında yurt dışında ve ülkemizde pek çok araştırma yapıımıştır. Son yıllarda özellikle Şema Terapi alanında yapılan çalışmalarda bariz bir çoğalma gözlemlenmektedir. Şema terapisi ile ilgili yapılan çalışmalara baktığımızda depresyon üzerine Shah ve Waller'in 2000'li yıllarda, Renner ile arkadaşlarının; çocukluk dönemi depresyonu olarak da Rusinek ve arkadaşlarının ve Curtin'in araştırmaları ön plana çıkmaktadır (10,16,18-19). McGinnve arkdaşlarının travma üzerine yaptıkları araştırmaları, yeme 
bozuklukları ile ilgili olarak da Meyer ve Gillings'in, Turner ve arkadaşlarının çalışmaları; antisosyal kişilik bozuklugu ile ilgili ise Petrocelli, ve arkadaşlarının araştırmaları; şema modeli kapsamında çalışılan bozukluklardan bazılarıdır (20-23).

Ayrıca ülkemizde Çakır ve Soygüt'ün (2009) bireylerin karşılaşı̆ı̆ı ebeveynlik biçimleri ile ilgili algıları ve ebeveynlerine karşı geliştirdikleri kişilerarası şemaların aracı rolünün incelendiği çalışması; Çakır, ve arkadaşları tarafından Young Ebeveynlik Ölçeği'nin geçerlilik ve güvenirlilik araştırması ve yine Çakır ve arkadşaları tarafından erken dönem uyum bozucu şemaların değerlendirilmesinin de yapıldığı Young Şema ÖIçeği Kısa Formu-3'ün geçerlilik ve güvenirlilik araştırması, Barışkın ve Eldoğan'ın erken dönem uyum bozucu şema alanları ile sosyal fobi semptomları arasındaki duyguları düzenleme zorluğunun aracı rolünün incelendiği çalışması ile Erden ve Yiğit'inçocukluk çağı istismar yaşantılarının ve genel ruhsal sağıı̆ın arasındaki ilişkide erken dönem uyum bozucu şemaların aracı rolünün incelendiği araştırmalar alana ait önemli çalışmalardır (24-26). Bu bağlamda çalışmamızda özel lisede eğitimlerini sürdüren 14-18 yaşındaki ergenlerin internet bağımlıı̆ı ile şema mekanizmaları arasındaki ilişkinin araştırıması amaçlanmıştır.

\section{Yöntem}

\section{Örneklem}

Ergenlerde internet bağımlı̆̆ı ıe şema mekanizmaları arasındaki ilişkiyi inceleyen bu çalışmada ilişkisel tarama modeli kullanıımıştır. Çalışma İstanbul İli Üsküdar İlçesi'nde Milli Eğitim Bakanlığına bağlı olarak eğitim-öğretim veren Özel İrfan Anadolu Lisesi'nde eğitim gören 14-18 yaş grubu ergenlerden oluşmaktadır. Veri toplama sürecinde örnekleme Sosyo-Demografik Bilgi Formu, Young Şema Ölçeği ve Internet Bağımlılık Ölçeği uygulanmıştır. Örneklemde yer alan kişilerin soruları cevaplarken ortaya çıkabilecek bilgi eksikliği, hatalı cevaplama, boş bırakma gibi durumların ortaya çıkabilme intimali göz önünde bulundurularak örneklem 14-18 yaş grubunda olan, bedensel ve nörolojik herhangi bir probleminin olmayan kişilerden oluşturulmuştur. Çalışmaya katıımda gönüllülük esastır. Böylece araștırmanın çalıșma örneklemi, Üsküdar IIlçesi'ndeki Özel İrfan Anadolu Lisesi'nin 1, 2, 3 ve 4. sınılarında eğitimlerini sürdürmekte olan 14-18 yaş grubu ergenleri temsil eden 75'i kı, 72'si erkek, 1 kişide cinsiyetini belirtmemiş toplam 148 öğrenciden oluşmuş ve istatistiksel çözümlemeler bu gruptan elde edilen veriler üzerinden gerçekleştirilmiş̧ir.

\section{İşlem}

Araştırmanın uygulanabilmesi için Üsküdar Üniversitesi Girişimsel Olmayan Araştırmalar Etik Kurulu'ndan 25/11/2015 tarihli B.08.6.YÖK.2ÜS.0.05.0.06/2015/192 sayılı etik kurul izni ve Çalışmanın yapılacağı okul için yazılı onay alınmıştır. Araştırmanın yapıldığı lise müdürlüğü ve ailelerinin bilgisi dahilinde gönüllü olarak çalışmaya katılacak öğrencilerden aydınlatımış onamları alınmışı̧ı. Çalışma grubumuza Young Şema ÖIçeği ve İnternet Bağımlıık Ölçeği uygulanmıştır. Ayrıca araştırmacı tarafından farklı değişkenlerin istatistiksel olarak analiz edilebilmesi için de on sorudan oluşturulmuş sosyo-demografik bilgi formu ile ergenlerin verdikleri cevaplar doğrultusunda veriler toplanmıştır.

\section{Veri Toplama Araçları}

Araştırmada Sosyo-Demografik Bilgi Formu, Young Şema Ölçeği ve İnternet Bağımlıık Ölçeği kullanılmıştır.

\section{Sosyodemografik Bilgi Formu}

Araştırmanın çalışma grubunu oluşturan ergenlerin cinsiyet, yaş, kardeş sayısı, okunulan sınıf, son dönemdeki not ortalaması, anne-babanın hayatta olma, birliktelik ve eğitim durumu, ailenin toplam geliri ve internetin kullanım amaçlarını gösteren bilgilerin yer aldığı on sorudan oluşan bireysel bir bilgi formu hazırlanmıştır.

\section{Young Şema Ölçeği}

Young tarafından Şema Terapinin temelini oluşturan kısa formu, Bağlantısız olma ve Reddetme, Hasar 
Görmüş Özerklik ve Performans, Zedelenmiş Sınırlar, Diğerler Yönelimlik, Aşırı Tetikte Olma ve Ketleme Şema Sahasını içeren 18 alt kategoride ele alınmaktadır. Alt ölçekler; Terk Edilme, Şüphecilik, Duygusal Yoksunluk, Kusurluluk, Sosyal İzolasyon, Bağımlılık/Yetersizlik, Dayanıksızlık veya Zarar Görme, Gelişmemiş Benlik/içiçecilik, Başarısızlık, Haklılık, Yetersiz Özdenetim, Boyun Eğicilik, Kendini Feda Etme, Onay Arama, Karamsarlık, Duyguları Ketleme, Yüksek Standartlar ve Cezalandırıcılık şeklinde isimlendirilmektedir. 90 maddeden meydana gelen ölçeğe katılanlar, maddelerin her birini 6'lı Likert üzerinden derecelendirmektedir. Ölçeğin orijinal formundaki her alt ölçek 5 maddeden oluşarak, bunun sonucunda alt ölçeklerden elde edilen puanlar 5 ile 30 arasında değişim gösterebilmektedir (26). Bu ölçeğin ülkemizdeki geçerlik-güvenirlik çalışmaları Dağ (1991) tarafından yürütülmüştür (27).

\section{İnternet Bağımlıık Ölçeği}

Sağlıksız internet kullanımının belirlenmesi amacıyla Young'ın (1998) geliştirdiği ve Bayraktar'ın (2001) Türkçemize uyarlamış olduğu İnternet Bağımlıık Ölçeği kullanılmıştır. K. Young'ın (1998) , DSM-IV'teki "Psikoaktif Maddeye Bağımlıı" kriterlerinden adapte edilen ve 20 sorudan oluşan bir "İnternet Bağımlıık Ölçeği" meydana getirilmiştir. 6'lı likert tipi şeklindeki internet Bağımlılık Ölçeği'nde katılımcılardan 6 alternatiften birinin seçilmesi istenilmektedir. Bu seçenekler 5, 4, 3, 2, 1 ve 0 olarak puanlandırımaktadır. Puan olarak 80 ve üzerinde alanların "Sağlıksız İnternet Kullanıcıları", 50-79 arasında alanların "Sınırlı Belirtiler Görülen Kullanıcılar", 50 puan ve altı alanların ise "Belirti Göstermeyen Kullanıcılar" olarak tanımlandığı belirtilmektedir (28).

\section{Veri Analizi}

Verilerin analizi SPSS 21.0 programı ile yapılmış ve \%95 güven düzeyi ile çalışılmıştır. Analizlerdeki uygun testin tercih edilmesinde normallik analizi neticesine göre karar verilmiştir. Normalliğin belirlenmesi amacıyla yapılan Shapiro-Wilk testi sonucuna göre normal dağılım gösteren ölçeklerin analizinde parametrik testlerin, normal dağııım göstermeyenlerde parametrik olmayan testlerin kullanılmasına karar verilmiştir. Cinsiyet ve ölçeklerin karşılaștırımasında Mann Whitney U testi kullanıImıștır. İnternetin kullanım amacını belirlemek için de Mann Whitney U testi kullanıımıştır. Internet bağımlıık ölçeğinin yaşa göre değerlendirilmesinde Kruskall Wallis $\mathrm{H}$ testi kullanılmıştır. $\mathrm{p}<0.05$ değeri anlamlı olarak kabul edildi.

\section{Bulgular}

Çalışmada katılımcıların demografik bilgileri şu şekildedir. Ankete cevap veren katılımcılardan cinsiyeti kız olanların oranı \%51,0; erkek olanların oranı \%49,0; 14 yaşında olanların oranı $\% 12,3 ; 15$ yaşında olanların oranı \%32,2; 16 yaşında olanların oranı 30,8; $17-18$ olanların oranı \%24,7; tek çocuk olanların oranı $\% 6,8 ; 1$ kardeşi olanların oranı \%37,2; 2 ve daha fazla kardeşi olanların oranı \%56,1; 9.sınıfta okuyanların oranı \%28,0; 10.sınıfta okuyanların oranı \%35,0; 11.sınifta okuyanların oranı \%18,2; 12 .sınıfta okuyanların oranı \%18,9'dur (Tablo 1).

Tablo 1. Ergenlerde internet kullanımı ile ilgili demografik bulgular

\begin{tabular}{|l|c|c|}
\hline Cinsiyet & Medyan & Minimum-Maksimum \\
\hline Kız & 75 & 51 \\
\hline Erkek & 72 & 49 \\
\hline Internet kullanım sebebi & & \\
\hline Eğlence (oyun, tv izleme, müzik dinleme vb) & 83 & 58,9 \\
\hline Iletişim (e-mail, sohbet, mesaj) & 34 & 24,1 \\
\hline Eğitim (araştırma ve ödev yapma) & 15 & 10,6 \\
\hline Diğer-Ticari (alışveriş, bankacılık) & 9 & 6,4 \\
\hline
\end{tabular}

Örneklemde yer alan bilgilere göre katılımcıların \% 58,9'unun ( $n=83$ ) eğlence (oyun, tv izleme, müzik dinleme vb), \%24,1'inin ( $n=34$ ) iletişim (e-mail, sohbet, mesaj), \% 10,6 ( $n=15)$ eğitim (araştırma ve ödev yapma), \% 6,4'ünün ( $\mathrm{n}=9$ ) diğer-ticari (alışveriş, bankacılık) amacıyla interneti kullandıkları görülmüştür. 
İnternet bağımılı̆ı̆ını yaşa göre incelediğimizde ise; farklı yaş grupları arasında İnternet Bağımlılı Ölçeği puanı açısından istatistiksel olarak anlamlı farkılık bulunmaktadır $(p<0,05) .14$ yaşında olanların söz konusu ölçek için puan sıra ortalamaları 68,92; 15 yaşında olanların 78,55; 16 yaşında olanların 60,58; 17-18 yaşında olanların 85,35’tir. Buna göre 17-18 yaşında olanların İnternet Bağımlıık Ölçeği puan sıra ortalamaları en yüksektir (Tablo 2).

Tablo 2. İnternet Bağımlılık ölçeğine göre ikigrubun verilerinin karşılaştırılması

\begin{tabular}{|c|c|c|c|}
\hline & Ort & U & $P$ \\
\hline \multicolumn{4}{|l|}{ Cinsiyet } \\
\hline $\mathrm{KIz}$ & 78,24 & \multirow[t]{2}{*}{$2382,000^{\star}$} & \multirow[t]{2}{*}{,218 } \\
\hline Erkek & 69,58 & & \\
\hline \multicolumn{4}{|l|}{ Yaş } \\
\hline 14 & 68,92 & \multirow[t]{4}{*}{$7,917^{\star \star}$} & \multirow[t]{4}{*}{,048 } \\
\hline 15 & 78,55 & & \\
\hline 16 & 60,58 & & \\
\hline $17-18$ & 85,35 & & \\
\hline \multicolumn{4}{|l|}{ İnternet kullanım sebebi } \\
\hline Eğlence(oyun, tv izleme,müzik dinleme vb) & 80,62 & \multirow[t]{4}{*}{$21,398^{*}$} & \multirow[t]{4}{*}{, 000} \\
\hline Iletişim (e-mail, sohbet, mesaj) & 71,46 & & \\
\hline Eğitim (arasstırma ve ödev yapma ) & 34,03 & & \\
\hline Diğer- Ticari (alışveriş, bankacılık) & 42,17 & & \\
\hline
\end{tabular}

Örneklemde internet bağımlıık ölçeği cinsiyete göre değerlendirildiğinde; internet bağımlı̆̆ında cinsiyetler arasında farkllık yoktur $(p=0,218)$. Internet bağımllık ölçeğinin cinsiyet ile ilişkisi incelendiğinde istatistiksel olarak fark bulunmamıştır $(p>0,5)$ (Tablo 2). İnterneti daha çok hangi amaçla kullandığı farklı olan gruplar arasında İnternet Bağımlılık Ölçeği puanları açısından istatistiksel olarak anlamlı farkılık bulunmaktadır $(p<0,05)$. İnterneti daha çok Eğlence (oyun, tv izleme, müzik dinleme vb) amacıyla kullananların söz konusu ölçek için puan sıra ortalamaları 80,62; illetişim ( e-mail, sohbet, mesaj) amacıyla kullananların 71,46; Eğitim (araştırma ve ödev yapma ) amacıyla kullananların 34,03; Diğer- Ticari (alışveriş, bankacılık) amacıyla kullananların 42,17'dir. Buna göre interneti daha çok Eğlence (oyun, tv izleme, müzik dinleme vb) amacıyla kullananların İnternet Bağımlılık Ölçeği puan sıra ortalamaları en yüksektir. Çalışmamızda gruplar internet bağımlılık ölçeğinin yanı sıra Young Şema Ölçeği de değerlendirilmiştir. Young Şema Ölçeğinin cinsiyete göre değerlendirilmesinde Mann Whitney Testi kullanılmıştır.

Kız ile erkek grupları arasında duygusal yoksunluk; kuşkuculuk; sosyal izolasyon; kusurluluk; bağımlılık; dayanıksızık; boyun eğicilik; duyguları bastırma; yüksek standartlar; onay arama; karamsarlık; cezalandıııılık; iç/içelik gelişmemiş benlik; internet Bağımlılık Ölçeği; puanları açısından istatistiksel olarak anlamlı farklılık bulunmamaktadır ( $p>0,05)$ (Tablo 3). Kız ile erkek grupları arasında Terk Edilme puanı açısından istatistiksel olarak anlamlı farklılık bulunmaktadır $(p<0,05)$. Kızların söz konusu puan için sıra ortalamaları 81,81; erkeklerin 65,86'dır. Buna göre kızların Terk Edilme puanı sıra ortalamaları daha yüksektir. Kız ile erkek grupları arasında Başarısızlık puanı açısından istatistiksel olarak anlamlı farklılık bulunmaktadır $(p<0,05)$. Kızların söz konusu puan için sıra ortalamaları 80,99; erkeklerin 66,72 'dir. Buna göre kızların Başarısızık puanı sıra ortalamaları daha yüksektir.

İnternetin farklı gruplar arasında hangi amaçla kullanıldığını belirlemek için Mann Whitney Testi yapılmıştır. Interneti daha çok hangi amaçla kullandığı farkı olan gruplar arasında Duygusal Yoksunluk; Terk Edilme; Kuşkuculuk; Sosyal İzolasyon; Kusurluluk; Bağımlılık; Dayanıksızık; Boyun Eğicilik; Duyguları Bastırma; Yüksek Standartlar; Onay Arama; Karamsarlık; Cezalandııııılık; Başarısızlık; İç/lçelik Gelişmemiş Benlik; puanları açısından istatistiksel olarak anlamlı farklıık bulunmamaktadır ( $p>0,05)$ (Tablo 4). 
Çalışmamızda internet bağımlılık ölçeğinin şema özellikleri ile ilişkisi incelenmiştir. Elde edilen veriler Tablo 5'de yer almaktadır. İnternet bağımlıı̆ı ile Kusurluluk, Yetersiz Özdenetim ve Boyun Eğicilik arasında pozitif yönlü orta kuvvetli, Onay Arama, Sosyal İzolasyon, Duyguları Bastırma, Dayanıksızlık, Kuşkuculuk, Hakılık, Kendini Feda Etme, İç/lçelik Gelişmemiş Benlik, Bağımlılık, Terk Edilme ve Karamsarlık arasında pozitif yönlü zayıf ve Duygusal Yoksunluk ve Başarııızlık arasında pozitif yönlü çok zayıf ilişki bulunmaktadır (Tablo 5).

\section{Tablo 3. Young Şema Ölçeğinin cinsiyete göre incelenmesi}

\begin{tabular}{|c|c|c|c|c|}
\hline Şema & Cinsiyet & Sira Ort. & U & P \\
\hline \multirow[t]{2}{*}{ Duygusal Yoksunluk } & KIZ & 75,39 & \multirow[t]{2}{*}{2596,000} & \multirow[t]{2}{*}{,685 } \\
\hline & Erkek & 72,56 & & \\
\hline \multirow[t]{2}{*}{ Terk Edilme } & $\mathrm{KIZ}$ & 81,81 & \multirow[t]{2}{*}{2114,000} & \multirow[t]{2}{*}{, 023} \\
\hline & Erkek & 65,86 & & \\
\hline \multirow[t]{2}{*}{ Kuşkuculuk } & $\mathrm{KIZ}$ & 79,93 & \multirow[t]{2}{*}{2255,500} & \multirow[t]{2}{*}{,084 } \\
\hline & Erkek & 67,83 & & \\
\hline \multirow[t]{2}{*}{ Sosyal İzolasyon } & $\mathrm{KIZ}$ & 72,65 & \multirow[t]{2}{*}{2599,000} & \multirow[t]{2}{*}{ 695 } \\
\hline & Erkek & 75,40 & & \\
\hline \multirow[t]{2}{*}{ Kusurluluk } & KIZ & 76,17 & \multirow[t]{2}{*}{2537,500} & \multirow[t]{2}{*}{, 527} \\
\hline & Erkek & 71,74 & & \\
\hline \multirow[t]{2}{*}{ Bağımlılık } & $\mathrm{KIZ}$ & 73,41 & \multirow[t]{2}{*}{2655,500} & \multirow[t]{2}{*}{, 862} \\
\hline & Erkek & 74,62 & & \\
\hline \multirow[t]{2}{*}{ Dayanıksızlık } & $\mathrm{KIZ}$ & 79,76 & \multirow[t]{2}{*}{2268,000} & \multirow[t]{2}{*}{,094 } \\
\hline & Erkek & 68,00 & & \\
\hline \multirow[t]{2}{*}{ Boyun Eğicilik } & $\mathrm{KIZ}$ & 74,92 & \multirow[t]{2}{*}{2631,000} & \multirow[t]{2}{*}{, 789} \\
\hline & Erkek & 73,04 & & \\
\hline \multirow[t]{2}{*}{ Duyguları Bastırma } & KIZ & 75,56 & \multirow[t]{2}{*}{2583,000} & \multirow[t]{2}{*}{ 650 } \\
\hline & Erkek & 72,38 & & \\
\hline \multirow[t]{2}{*}{ Yüksek Standartlar } & $\mathrm{KIZ}$ & 73,41 & \multirow[t]{2}{*}{2656,000} & \multirow[t]{2}{*}{,864 } \\
\hline & Erkek & 74,61 & & \\
\hline \multirow[t]{2}{*}{ Onay Arama } & $\mathrm{KIZ}$ & 79,84 & \multirow[t]{2}{*}{2262,000} & ,089 \\
\hline & Erkek & 67,92 & & \\
\hline Karamsarlık & $\mathrm{KIZ}$ & 78,91 & 2332,000 & ,153 \\
\hline & Erkek & 68,89 & & \\
\hline Cezalandırıcılık & $\mathrm{KIZ}$ & 72,38 & 2578,500 & 637 \\
\hline & Erkek & 75,69 & & \\
\hline Başarısızlık & $\mathrm{KIZ}$ & 80,99 & 2175,500 &, 042 \\
\hline & Erkek & 66,72 & & \\
\hline $\begin{array}{l}\text { İç/lçelik Gelişmemiş } \\
\text { Benlik }\end{array}$ & $\begin{array}{l}\text { KIz } \\
\text { Erkek }\end{array}$ & $\begin{array}{l}80,01 \\
67,74\end{array}$ & 2249,000 & ,080 \\
\hline
\end{tabular}

Mann Whitney Testi

Tablo 4. Young Şema Ölçeğinin internet kullanım amacına göre incelenmesi

\begin{tabular}{|c|c|c|c|c|}
\hline \multicolumn{2}{|c|}{ İterneti daha çok hangi amaçla kullanıyorsunuz? } & $\begin{array}{l}\text { Sira } \\
\text { Ort. }\end{array}$ & $X 2$ & $P$ \\
\hline \multirow{4}{*}{$\begin{array}{l}\text { Duygusal } \\
\text { Yoksunluk }\end{array}$} & Eğlence (oyun, tv izleme, müzik dinleme vb) & 72,48 & \multirow[t]{4}{*}{4,588} & \multirow[t]{4}{*}{,205 } \\
\hline & İletişim ( e-mail, sohbet, mesaj) & 59,66 & & \\
\hline & Eğitim (araştırma ve ödev yapma ) & 83,80 & & \\
\hline & Diğer- Ticari (alışveriş, bankacılık) & 78,89 & & \\
\hline \multirow[t]{3}{*}{ Terk Edilme } & Eğlence (oyun, tv izleme, müzik dinleme vb) & 70,64 & \multirow[t]{3}{*}{0,791} & \multirow[t]{3}{*}{852} \\
\hline & İletişim ( e-mail, sohbet, mesaj) & 70,44 & & \\
\hline & Eğitim (araştırma ve ödev yapma ) & 78,50 & & \\
\hline
\end{tabular}




\begin{tabular}{|c|c|c|c|c|}
\hline & Diğer- Ticari (alışveriş, bankacılık) & 63,94 & & \\
\hline \multirow[t]{4}{*}{ Kuşkuculuk } & Eğlence (oyun, tv izleme, müzik dinleme vb) & 69,72 & \multirow[t]{4}{*}{0,392} & \multirow[t]{4}{*}{942} \\
\hline & İletişim ( e-mail, sohbet, mesaj) & 71,01 & & \\
\hline & Eğitim (araştırma ve ödev yapma ) & 76,53 & & \\
\hline & Diğer- Ticari (alışveriş, bankacılık) & 73,50 & & \\
\hline \multirow{4}{*}{$\begin{array}{l}\text { Sosyal } \\
\text { İzolasyon }\end{array}$} & Eğlence (oyun, tv izleme, müzik dinleme vb) & 73,72 & \multirow[t]{4}{*}{3,440} & \multirow[t]{4}{*}{329} \\
\hline & İletişim ( e-mail, sohbet, mesaj) & 60,07 & & \\
\hline & Eğitim (araştırma ve ödev yapma ) & 79,07 & & \\
\hline & Diğer- Ticari (alışveriş, bankacılık) & 73,72 & & \\
\hline \multirow[t]{4}{*}{ Kusurluluk } & Eğlence (oyun, tv izleme, müzik dinleme vb) & 73,48 & \multirow[t]{4}{*}{1,846} & \multirow[t]{4}{*}{,605 } \\
\hline & İletişim ( e-mail, sohbet, mesaj) & 62,94 & & \\
\hline & Eğitim (araştırma ve ödev yapma ) & 75,73 & & \\
\hline & Diğer- Ticari (alışveriş, bankacılık) & 70,67 & & \\
\hline \multirow[t]{4}{*}{ Bağımlılık } & Eğlence (oyun, tv izleme, müzik dinleme vb) & 73,22 & \multirow[t]{4}{*}{1,400} & \multirow[t]{4}{*}{,706 } \\
\hline & İletişim ( e-mail, sohbet, mesaj) & 69,46 & & \\
\hline & Eğitim (araştırma ve ödev yapma ) & 60,27 & & \\
\hline & Diğer- Ticari (alışveriş, bankacilık) & 74,22 & & \\
\hline \multirow[t]{4}{*}{ Dayanıksızlık } & Eğlence (oyun, tv izleme, müzik dinleme vb) & 70,27 & \multirow[t]{4}{*}{1,003} & \multirow[t]{4}{*}{800} \\
\hline & İletişim ( e-mail, sohbet, mesaj) & 71,87 & & \\
\hline & Eğitim (araştırma ve ödev yapma ) & 78,53 & & \\
\hline & Diğer- Ticari (alışveriş, bankacılık) & 61,89 & & \\
\hline \multirow[t]{4}{*}{ Boyun Eğicilik } & Eğlence (oyun, tv izleme, müzik dinleme vb) & 69,13 & \multirow[t]{4}{*}{1,749} & \multirow[t]{4}{*}{,626 } \\
\hline & İletişim ( e-mail, sohbet, mesaj) & 77,84 & & \\
\hline & Eğitim (araştırma ve ödev yapma ) & 72,17 & & \\
\hline & Diğer- Ticari (alışveriş, bankacılık) & 60,44 & & \\
\hline \multirow{4}{*}{$\begin{array}{l}\text { Duyguları } \\
\text { Bastırma }\end{array}$} & Eğlence (oyun, tv izleme, müzik dinleme vb) & 72,04 & \multirow[t]{4}{*}{0,923} & \multirow[t]{4}{*}{,820 } \\
\hline & İletişim ( e-mail, sohbet, mesaj) & 66,22 & & \\
\hline & Eğitim (araştırma ve ödev yapma ) & 70,90 & & \\
\hline & Diğer- Ticari (alışveriş, bankacılık) & 79,61 & & \\
\hline \multirow{4}{*}{$\begin{array}{l}\text { Yüksek } \\
\text { Standartlar }\end{array}$} & Eğlence (oyun, tv izleme, müzik dinleme vb) & 74,37 & \multirow[t]{4}{*}{2,332} & \multirow[t]{4}{*}{, 506} \\
\hline & İletişim ( e-mail, sohbet, mesaj) & 61,94 & & \\
\hline & Eğitim (araştırma ve ödev yapma ) & 70,50 & & \\
\hline & Diğer- Ticari (alışveriş, bankacılık) & 75,00 & & \\
\hline \multirow[t]{4}{*}{ Onay Arama } & Eğlence (oyun, tv izleme, müzik dinleme vb) & 69,58 & \multirow[t]{4}{*}{0,397} & \multirow[t]{4}{*}{941} \\
\hline & İletişim ( e-mail, sohbet, mesaj) & 72,57 & & \\
\hline & Eğitim (araştırma ve ödev yapma ) & 71,27 & & \\
\hline & Diğer- Ticari (alışveriş, bankacılık) & 77,72 & & \\
\hline Karamsarlık & Eğlence (oyun, tv izleme, müzik dinleme vb) & 68,44 & 2,577 & 461 \\
\hline & İletişim ( e-mail, sohbet, mesaj) & 70,31 & & \\
\hline
\end{tabular}




\begin{tabular}{|c|c|c|c|c|}
\hline & Eğitim (araştırma ve ödev yapma ) & 86,77 & & \\
\hline & Diğer- Ticari (alışveriş, bankacılık) & 70,94 & & \\
\hline \multirow[t]{4}{*}{ Cezalandırıcılık } & Eğlence (oyun, tv izleme, müzik dinleme vb) & 69,46 & \multirow[t]{4}{*}{5,647} & \multirow[t]{4}{*}{, 130 } \\
\hline & İletişim ( e-mail, sohbet, mesaj) & 64,62 & & \\
\hline & Eğitim (araştırma ve ödev yapma ) & 93,80 & & \\
\hline & Diğer- Ticari (alışveriş, bankacılık) & 71,28 & & \\
\hline \multirow[t]{4}{*}{ Başarısızlık } & Eğlence (oyun, tv izleme, müzik dinleme vb) & 71,75 & \multirow[t]{4}{*}{2,435} & \multirow[t]{4}{*}{,487 } \\
\hline & İletişim ( e-mail, sohbet, mesaj) & 76,57 & & \\
\hline & Eğitim (araştırma ve ödev yapma ) & 63,20 & & \\
\hline & Diğer- Ticari (alışveriş, bankacılık) & 56,00 & & \\
\hline \multirow{4}{*}{$\begin{array}{l}\text { İç/İçelik } \\
\text { Gelişmemiş } \\
\text { Benlik }\end{array}$} & Eğlence (oyun, tv izleme, müzik dinleme vb) & 66,81 & \multirow[t]{4}{*}{ 2,365 } & \multirow[t]{4}{*}{, 500} \\
\hline & İletişim ( e-mail, sohbet, mesaj) & 78,71 & & \\
\hline & Eğitim (araştırma ve ödev yapma ) & 72,70 & & \\
\hline & Diğer- Ticari (alışveriş, bankacılık) & 77,72 & & \\
\hline
\end{tabular}

\section{Tablo 5. İnternet bağımlığının şema özellikleri ile ilişkisi}

\begin{tabular}{|c|c|}
\hline 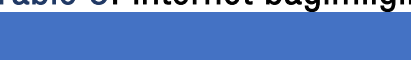 & İnternet Bağımlılık Ölçeği \\
\hline Duygusal Yoksunluk &, $189^{*}$ \\
\hline Terk Edilme &, $208^{*}$ \\
\hline Kuşkuculuk & ,256* \\
\hline Sosyal İzolasyon &, $263^{* *}$ \\
\hline Kusurluluk &, $317^{* *}$ \\
\hline Bağımlılık &, $214^{* *}$ \\
\hline Dayanıksızlık & ,260* \\
\hline Boyun Eğicilik &, $307^{*+}$ \\
\hline Kendini Feda Etme &, $217^{*+}$ \\
\hline Duyguları Bastırma & ,261* \\
\hline Yüksek Standartlar & 101 \\
\hline Haklılık & ,253** \\
\hline Yetersiz Özdenetim &, $313^{* *}$ \\
\hline Onay Arama & ,295* \\
\hline Karamsarlık &, $201^{*}$ \\
\hline Cezalandırıcılık &, 110 \\
\hline Başarısızlık &, $179^{*}$ \\
\hline İç/i̇çelik Gelişmemiş Benlik &, $217^{* *}$ \\
\hline
\end{tabular}

\section{Tartışma}

14-18 yaş grubundaki ergenlerin katıldığı, internet bağımlılığı ölçek puanı ve şema mekanizmaları arasındaki iliş̧kiyi incelediğimiz bu çalışmamızda internet bağımlıı̆̆ı ve şema mekanizmaları arasında pozitif yönlü bir ilişki olduğu saptanmıştır. İnternet bağımlıı̆̆ının cinsiyete bağımlı olup olmadığını belirlemek için birçok çalışma yapılmıştır ve bu konuda farklı görüşler bulunmaktadır. Çalışmamızın sonucuna göre internet bağımlılı̆ı cinsiyete göre değişmemektedir. Balcı ve Gülnar'ın yaptıkları çalışma bu bulgumuzu desteklemektedir. Yapılan çalışmaya göre internet bağımılı̆̆ı üzerinde cinsiyet gibi demografik özelliklerin 
bir etkisi yoktur (29). Bunun yanı sıra Taylan ve Işık, Lee ve arkadaşları ve Kim ve arkadaşları da yaptıkları çalışmada internet bağımlıığı ve cinsiyet arasında bir ilişki bulunmadığını tespit etmişlerdir (30-32). Aloi ve arkadaşlarının 2020 yılında yaptığı bir çalışmaya göre de cinsiyet ve internet bağımlıığı arasında bir ilişki bulunamamıştır (33). Ancak internet bağımlılığının cinsiyete göre değiştiğini gösteren yayınlar da mevcuttur $(34,35)$. Su ve arkadaşları yaptıkları bir çalışmada ise internet bağımlıı̆ı̆ının cinsiyete bağımlı olarak ortaya çıkması ülkeler bazında değişmektedir. Bu çalışmaya göre Asya'da cinsiyetin internet bağımılığına etkisi yüksek iken Kuzey Amerika'da düşüktür (36). Yine Öksüz'ün ülkemizdeki internet bağımlılı̆ı üzerine yaptığı araştırmada ise lise çağında erkek öğrencilerin kız öğrencilere göre internet bağımlılık seviyesinin yüksek olduğu belirlenmiştir ancak bu fark küçük düzeydedir (37).

İnterneti daha çok hangi amaçla (eğlence, iletişim, eğitim, diğer-ticari) kullandığı farklı olan gruplar arasında şema mekanizmaları arasında anlamlı bir farklılık bulunmamaktadır. Fakat İnternet Bağımlılık Ölçeği puanları açısından anlamlı bir farklıık bulunmaktadır. Çalışmamızda olduğu gibi Doğan'ın internet bağımlılığı yaygınlığı ile ilgili çalışmasında da ergenlerin internet kullanım amacına göre internet bağımlıık durumları arasında anlamlı bir farklıık bulunmuştur. Bu çalışmaya göre ergenlerin interneti daha çok chat yapma amacı ile kullandığı görülmüştür (8). Yılmaz ve arkadaşlarına göre interneti öncelikle sohbet ve oyun amaçlı kullanan öğrencilerin toplam bağımlıık değerleri; interneti kullanırken önceliği sosyal ağ, müzik-film ve ödev-araştırma olan öğrencilerden daha fazladır (14). Şahin'in üniversite öğrencileri üzerinde yapmış olduğu internet bağımlı̆̆ı ve saldırganlık ile ilgili çalışmasında ise internet kullanım amacı eğlence olan öğrencilerin interneti eğitim amacıyla kullanan öğrencilere göre puanlarının anlamlı olarak daha yüksek olduğu tespit edilmiştir (38). Kraut ve arkadaşları, ergenlerdeki internet kullanımının en çok iletişimi sağlamak amacıyla gerçekleştirildiğini; Yang ve Tung ise internetin eğlence ve bilgiye ulaşmada istek uyandıran ehemmiyetli iki etken olduğunu ifade etmişlerdir $(39,40)$. Bu çalışmaların bir benzerini gerçekleştiren Boyd, ergen gençlerin internet arkadaşlığında nerdeyse bir mecburiyet durumunun oluştuğunu, web sayfası kullanımının, gencin arkadaşılık yaptığı kişiler ya da gruplar arasında popülerite kazanmasında etkili olduğunu, gencin internetteki arkadaşlarıyla görüşmediğinde arkadaşlarının grupları tarafından soyutlandığını saptamıştır (7). Lise öğrencilerinin internet kullanım amaçlarının belirlenmesi için Çevik ve arkadaşları tarafından yapılan araştırmada kız öğrencilerin \%39,7'si interneti ders içerikli konular için kullanırken, erkek öğrencilerin ise \%26,9'unun interneti eğitim amaçlı kullandığı görülmektedir. Ayrıca kızların \%42,4'nün erkeklerin ise \%37,3'ünün genellikle arkadaşlarıyla sohbet (Messenger, facebook vb.) amaçlı interneti kullandıkları saptanmışı̇ (41).

Young Şema ölçeği birçok çalışmada internet bağımlılı̆ı ile ilişkilendirilmiştir. Horwitz’in görüşüne göre ergenler, interneti birkaç fiziksel sosyal etkileşimden kaynaklanan depresif duygularla başa çıkma stratejisi olarak kullanabilirler (42). Shajari ve arkadaşlarının Young Şema Ölçeğini kullanarak yapmış olduğu bir çalışmada ise tüm alanların internet bağımlılığı ile ilişkili olduğu belirlenmişsir (43). Aloi ve arkadaşları yaptıkları çalışmada internet bağımlıı̆ı ve şema mekanizmalarının tümünde yüksek puan almıştır (33). Çalışmamızın sonucuna göre şema mekanizmaları ile internet bağımlıl̆ğı arasında pozitif yönlü ilişki olduğu belirlenmiştir. Elde ettiğimiz sonuçlar literatürle uyumludur. Bu sonuçlara göre şema mekanizması internet bağımlılığı konusunda değerlendirilebilecek bir yöntemdir diyebiliriz.

Çalışmamıza göre şemalar ve cinsiyet değişkeninin arasında istatistiki açıdan manidar bir farkklık bulunmamakla birlikte, kız ile erkek grupları arasında terk edilme, başarısızlık şemaları puanı açısından istatistiksel olarak anlamlı fark bulunmaktadır. Tortamış'ın yapmış olduğu araştırmasında erken dönemdeki uyumsuz şema mekanizmalarının cinsiyet açııından farkılık gösterip göstermediğine dair yapılan analizlerin sonucu, kadın ve erkek katılımcıların arasında manidar bir farklılık bulunmamaktadır. Kadın ve erkekler arasındaki şema mekanizmalarının manidar bir farklı̆ğın bulunmamasına dair elde edilen bulgular, şema mekanizmalarının büyük bölümünün cinsiyet değişkeni bakımından manidar biçimde farkıllaşmadığını gösteren alanyazınla tutarlıık göstermektedir (44). Ayrıca Boysan'ın çalışmasında bizim araştırmamızdan farklı olarak baş etme becerileri açısından cinsiyetler arasında istatistiksel yönde önemli bir farklılık bulunmamaktadır (45). 
Çalışmamı İstanbul ili Üsküdar ilçesinde bulunan bir özel lisede 2015 - 2016 Eğitim- Öğretim Yııında öğrenim gören 14-18 yaş grubunda olan; bedensel ve nörolojik problemi olmayan öğrenci grubuyla sınırlıdır. Aynı zamanda incelenen değişkenler uygulanan ölçme araçlarından elde edilen verilerle sınırlıdır. Çalışmanın bağımsız değişkenleri çalışmaya katılan gönüllü lise öğrencilerinden elde edilen bilgilerle sınırlıdır. Elde edilen tüm veriler, özel lisede eğitim gören gönüllü lise öğrencilerinin ölçeklere verdikleri cevaplarla sınırlıdır.

Örneklem grubunun daha da büyütülerek, ergenlik dönemi oluşan şemalara ilişkin daha kapsamlı ve farklı alanlarda çalışmalar yapılarak, ergenlik döneminde bozulabilecek şemalara yönelik tedbirler alınması yetişkinlikte yaşanması olası problemlerin azaltılmasına ve toplum ruh sağlığının iyileştirilmesine yarar sağlayabilir. Ayrıca internet bağımlılı̆ı ile ilgili ailelere ve ergenlere yönelik bilinçlendirme çalışmaları yapılarak teknolojinin sağıklı ve bilinçli kullanımı için eğitimler verilebilir.

\section{Kaynaklar}

1. Arısoy Ö. İnternet bağımlıı̆ğı ve tedavisi. Psikiyatride Güncel Yaklaşımlar 2009; 1(1): 55-67.

2. Chiu SI, Lee JZ, Huang DH. Video game addiction in children and teenagers in Taiwan. Cyberpsychol Behavior 2004; 7(5): 571-581.

3. Young KS. Internet addiction: The emergence of a new clinical disorder. Cyberpsychol Behav 1998; 1(3): 237244.

4. Gökçearslan Ş, Günbatar MS. Ortaöğrenim öğrencilerinde internet bağımlılığı. Eğitim Teknolojisi Kuram ve Uygulama 2012; 2(2): 10-24.

5. Ancel G, Acikgoz I, Ayhan AGY. The relationship between problematic internet using emotional intelligence and some sociodemographic variables. Anadolu Psikiyatri Derg 2015; 16(4): 255-264.

6. Bayhan V. Lise öğrencilerinde internet kullanma alışkanlığı ve internet bağımlıı̆ı (Malatya uygulaması). Akademik Bilişim'11 - XIII. Akademik Bilişim Konferansı Bildirileri Kitabı 2011

7. Boyd D. Taken out of context: American teen sociality in networked publics. SSRN Electronic Journal 2008; 1344756.

8. Doğan A. İnternet bağımlıı̆ı yaygınlı̆ı. Yüksek Lisans Tezi, İzmir: Dokuz Eylül Üniversitesi Eğitim Bilimleri Enstitüsü, Aile Eğitimi ve Danışmanlığı Anabilim Dalı Aile Eğitimi Ve Danışmanlığı Programı, 2013.

9. Esen E. Ergenlerde internet bağımlılığını yordayan psiko-sosyal değişkenlerin incelenmesi. Türk Psikolojik Danışma ve Rehberlik Dergisi 2011; 4(36), 127-138.

10. Harris AE, Curtin L. Parental perceptions, early maladaptive schemas, and depressive symptoms in young adults. Cognit Ther Res 2002; 26(3): 405-416.

11. Jang KS, Hwang SY, Choi JY. Internet addiction and psychiatric symptoms among Korean adolescents. J Sch Health 2008; 78(3): 165-171.

12. Taylan HH, Işık M. Sakarya'da ortaokul ve lise öğrencilerinde internet bağımlıı̆ı. Turkish Studies 2015; 10(6): 855-874.

13. Üneri Ö, Tanıdır C. Bir grup lise öğrencisinde internet bağımlılı̆ı değerlendirmesi: Kesitsel bir çalışma. Dusunen Adam 2011; 24(4): 265-272.

14. Yılmaz E, Şahin YL, Haseski Hi, Osman E. Lise öğrencilerinin internet bağımlıık düzeylerinin çeşitli değişkenlere göre incelenmesi: Balıkesir ili örneği. Eğitim Bilimleri Araştırmaları Dergisi 2014; 4(1): 133-144.

15. Young JE, Klosko JS, Weishaar ME, Kierdorf T. Schematherapie. Ein Praxisorientiertes Handbuch. Paderborn: Junfermann, 600, 2005.

16. Renner F, Lobbestael J, Peeters F, et al. Early maladaptive schemas in depressed patients: Stability and relation with depressive symptoms over the course of treatment. J Affect Disord 2012; 136(3): 581-590.

17. Young J, Klosko J, Weishaar E. Şema Terapi. 2. Baskı, İstanbul: Litera Yayıncılık, 2003.

18. Shah R, Waller G. Parental style and vulnerability to depression: The role of core beliefs. J Nerv Ment Dis 2000; 188(1): 19-25.

19. Rusinek S, Charbonnier E, Boudoukha A-H, et al. Early maladaptive schemas among children: A new way to screen for depressed children? Psicoterapia Cognitiva e Comportamentale 2013; 19(2): 157-168.

20. McGinn LK, Young JE, Sanderson WC. When and how to do longer term therapy without feeling guilty. Cognit Behav Pract 1995; 2(1): 187-212.

21. Meyer C, Gillings K. Parental bonding and bulimic psychopathology: The mediating role of mistrust/abuse beliefs. Int J Eat Disord 2004; 35(2): 229-233. 
22. Turner HM, Rose K, Cooper M. Schema and parental bonding in overweight and nonoverweight female adolescents. Int J Obes 2005; 29(4): 381-387.

23. Petrocelli JV, Glaser BA, Calhoun GB, Campbell LF. Cognitive schemas as mediating variables of the relationship between the self-defeating personality and depression. J Psychopathol Behav Assess 2001; 23(3): 183-191.

24. Soygüt G, Çakır Z. Ebeveynlik biçimleri ile psikolojik belirtiler arasındaki ilişkilerde kişilerarası şemaların aracı rolü: şema odaklı bir bakış. Turk Psikiyatri Derg 2009; 20(2): 144-152.

25. Soygüt G, Çakır Z, Karaosmanoğlu A. Ebeveynlik biçimlerinin değerlendirilmesi: Young ebeveynlik ölçeğinin psikometrik özelliklerine ilişkin bir inceleme. Türk Psikoloji Yazıları 2008; 11(22): 17-30.

26. Soygüt G, Karaosmanoğlu A, Çakır Z. Erken dönem uyumsuz şemaların değerlendirilmesi: Young Şema Ölçeği Kısa Form-3'ün psikometrik özelliklerine ilişkin bir inceleme. Turk Psikiyatri Derg 2009; 20(1): $75^{\star} 84$.

27. Dağ í. Belirti tarama listesi (SCL-90-R)'nin üniversite öğrencileri için güvenirliği ve geçerliği. Turk Psikiyatri Derg 1991; 2(1): 5-12.

28. Döner CY, Keser HTD. IIlköğretim öğrencilerinde internet bağımlılı̆ııın farklı değişkenlere göre incelenmesi. Yüksek Lisans Tezi, Ankara: Ankara Üniversitesi Eğitim Bilimleri Enstitüsü, 2011.

29. Batıgün AD, Kılıç N. İnternet bağımlılığı ile kişilik özellikleri, sosyal destek, psikolojik belirtiler ve bazı sosyodemografik değişkenler arasındaki ilişkiler. Türk Psikoloji Dergisi 2011; 26(67): 1-10.

30. Kim K, Ryu E, Chon MY, et al. Internet addiction in Korean adolescents and its relation to depression and suicidal ideation: a questionnaire survey. Int J Nurs Stud 2006; 43(2): 185-192.

31. Lee MS, Ko YH, Song HS, et al. Characteristics of Internet use in relation to game genre in Korean adolescents. Behav 2006; 10(2): 278-285.

32. Taylan H, Işı M. Internet addiction among secondary school and high school students in Sakarya. Turkish Studies 2015; 10(6): 855-874.

33. Aloi M, Verrastro V, Rania M, et al. The potential role of the early maladaptive schema in behavioral addictions among late adolescents and young adults. Front Psychol 2020; 10: 3022.

34. Gürcan N. Ergenlerin problemli internet kullanımları ile uyumları arasındaki ilişkinin incelenmesi. Konya: Selçuk Üniversitesi Eğitim Bilimleri Enstitüsü, 2010.

35. Taş I. Ergenlerde internet bağımlılı̆ı ve psikolojik belirtilerin çeşitli değişkenler açısından incelenmesi Anemon Muş Alparslan Üniversitesi Sosyal Bilimler Dergisi 2018; 6(1): 31-41.

36. Su W, Han X, Jin C, Yan Y, Potenza MN. Are males more likely to be addicted to the internet than females? A meta-analysis involving 34 global jurisdictions. Comput Hum Behav 2019; 99, 86-100.

37. Öksüz Ö. Cinsiyetin internet bağımllığı, problemli internet kullanımı, siber zorbalık ve siber mağduriyet değişkenleri üzerine etkisi: bir meta-analiz çalışması. Yüksek Lisans Tezi, İstanbul: Marmara Üniversitesi, Eğitim Bilimleri Enstitüsü, 2019

38. Şahin M. Üniversite öğrencilerinde internet bağımlılığı ve saldırganlık. Dusunen Adam 2014; 27(1): 43-52.

39. Kraut $R$, Patterson $M$, Lundmark V, et al. Internet paradox: A social technology that reduces social involvement and psychological well-being? Am Psychol 1998; 53(9): 1017-1031.

40. Yang SC, Tung CJ. Comparison of Internet addicts and non-addicts in Taiwanese high school. Comput Hum Behav 2007; 23(1): 79-96.

41. Kahraman S, Yalçin SA, Çevik C. Lise Öğrencilerinin internet kullanimi. 5th International Computer \& Instructional Technologies Symposium, 2011.

42. Horwitz AG, Hill RM, King CA. Specific coping behaviors in relation to adolescent depression and suicidal ideation. J Adolesc 2011; 34: 1077-1085

43. Shajari F, Sohrabi F, Jomehri F. Relationship between early maladaptive schema and internet addiction:a crosssectional study. Asian J Pharm Res Heal Care 2016; 8: 84.

44. Tortamış B. Sığınma evinde kalan kadınlarda şiddet öyküsü açıından travma sonrası stres bozukluğu, benlik saygısı ve beden algısının değerlendirilmesi. Yüksek Lisans Tezi, İstanbul: İstanbul Üniversitesi, 2009.

45. Boysan MY, Pişkin MTD. Üniversite öğrencilerinde erken dönem uyumsuz şemalar, başa çıkma stilleri ve öznel iyi oluş arasındaki ilişkilere yönelik bir model sınaması. Doktora Tezi, Ankara:Ankara Üniversitesi Eğitim Bilimleri Enstitüsü Eğitimde Psikolojik Hizmetler, 2012. 